\title{
Sosialisasi Deteksi Dini Kanker Payudara Dan Kanker Serviks Melalui Webinar Berjudul "Yuk Kenal Lebih Jauh Dengan Kanker Pembunuh Wanita Di Dunia"
}

\author{
Tri Wahyuni1, Desy Syswianti2 \\ Program Studi D3 Kebidanan Sekolah Tinggi Ilmu Kesehatan Karsa Husada Garut \\ Email korespondensi : tri3wahyuni2014@gmail.com
}

\begin{abstract}
Abstrak
Kanker merupakan penyakit yang menjadi penyumbang angka kematian cukup besar. Berdasarkan data Global Burden Cancer (Globocan) 2018, dari 18,1 juta angka kejadian kanker, sebanyak 9,6 juta jiwa terenggut nyawanya karena penyakit ini. Terdapat dua jenis kanker yang paling banyak diderita masyarakat Indonesia, yaitu kanker payudara dan kanker serviks. Kanker payudara memiliki angka kejadian 42,1 per 100 ribu penduduk dengan angka rata-rata kematian 17 per 100 ribu penduduk. Sedangkan untuk kanker serviks yaitu sebesar 23,4 per 100 ribu penduduk dengan angka kematian sebesar 13,9 per 100 ribu penduduk. Kegiatan pengabdian ini bertujuan untuk meningkatkan pengetahuan masyarakat mengenai deteksi dini kanker payudara dan kanker serviks yang menjadi penyebab kematian dari banyak wanita baik di Indonesia maupun di dunia. Metode yang digunakan yaitu sosialisasi melalui webinar dengan judul "Yuk Kenal Lebih Jauh Dengan Kanker Pembunuh Wanita Di Dunia" dengan menggunakan aplikasi Zoom, disesuaikan dengan situasi pandemic Covid 19 yang sedang terjadi pada saat ini. Kegiatan webinar diikuti oleh 50 orang peserta, terdiri dari 2 orang pemateri, 1 orang bidan desa merangkap sebagai moderator, dan 47 orang masyarakat dari wilayah kerja Puskesmas Tarogong Garut. Setelah dilakukan webinar, masyarakat menjadi lebih mengetahui tentang kanker payudara dan serviks yang diharapkan dapat menumbuhkan kesadaran masyarakat untuk dapat melakukan deteksi dini sehingga dapat mengurangi angka kejadian dan angka kematian yang ditimbulkan oleh kanker payudara dan serviks.
\end{abstract}

Kata Kunci : Deteksi Dini, Kanker Payudara, Kanker Serviks, Webinar

\begin{abstract}
Cancer is a disease that contributes to the death rate quite large. Based on 2018 Global Burden Cancer (Globocan) data, out of 18.1 million cancer incidence rates, 9.6 million people were killed because of this disease. There are two types of cancer that most people in Indonesia suffer, namely breast cancer and cervical cancer. Breast cancer has an incidence rate of 42.1 per 100 thousand population with an average mortality rate of 17 per 100 thousand population. Meanwhile, cervical cancer was 23.4 per 100 thousand population with a mortality rate of 13.9 per 100 thousand population. This service activity aims to increase public knowledge about early detection of breast cancer and cervical cancer which are the causes of death for many women both in Indonesia and in the world. The method used is socialization through a webinar with the title "Let's Get to Know More About Cancer, the World Killer," using the Zoom application, adjusted to the current situation of the Covid 19 pandemic. The webinar activity was attended by 50 participants, consisting of 2 presenters, 1 village midwife who doubles as a moderator, and 47 people from the work area of the Tarogong Garut Health Center. After the webinar, the public becomes more aware of breast and cervical cancer which is expected to raise public awareness to be able to carry out early detection so that it can reduce the incidence and mortality rate caused by breast and cervical cancer.
\end{abstract}

Keywords : Early Detection, Breast Cancer, Cervical Cancer, Webinars 


\section{PENDAHULUAN}

Kanker merupakan penyakit yang menjadi penyumbang angka kematian cukup besar. Kanker merupakan penyakit yang bisa menyerang siapa saja, baik laki-laki maupun perempuan. Namun, terdapat beberapa jenis kanker yang berisiko lebih tinggi dialami oleh perempuan, yakni kanker payudara dan serviks. Kedua jenis kanker ini merupakan salah satu pembunuh utama bagi perempuan di seluruh dunia.

Kanker serviks bersama kanker payudara menempati peringkat teratas penyebab kematian pada perempuan di berbagai negara termasuk Indonesia. Berdasarkan data Global Burden Cancer (Globocan) 2018, dari 18,1 juta angka kejadian kanker, sebanyak 9,6 juta jiwa terenggut nyawanya karena penyakit ini (Bray, 2018).

Terdapat dua jenis kanker yang paling banyak diderita masyarakat Indonesia, yaitu kanker payudara dan kanker serviks. Kanker payudara memiliki angka kejadian 42,1 per 100 ribu penduduk dengan angka rata-rata kematian 17 per 100 ribu penduduk. Sedangkan untuk kanker serviks yaitu sebesar 23,4 per 100 ribu penduduk dengan angka kematian sebesar 13,9 per 100 ribu penduduk (Pusat Data dan Informasi Kesehatan Kementerian Kesehatan RI, 2015). Garut merupakan salah satu Kabupaten di Provinsi Jawa Barat. Partisipasi masyarakat untuk melakukan deteksi dini kanker payudara di Kabupaten Garut masih sangat rendah. Hal tersebut dapat dilihat dari cakupan deteksi dini kanker payudara dengan pemeriksaan Clinical Breast Examination pada tahun 2016. Dari 2.55.173 wanita dengan kategori usia 30-50 tahun, hanya $2.090(1 \%)$ yang melakukan deteksi dini, dengan hasil deteksi 40 orang $(1,38 \%)$ mempunyai tumor atau benjolan di payudara (Witdiawati, 2019). Pada tahun 2017 Kabupaten Garut telah melaksanakan IVA Test tetapi baru di 16 Puskesmas yang berada di Kota dan sekitarnya, dari 3.914 wanita usia 30-50 tahun yang melakukan pemeriksaan terdapat 2 orang $(0.05 \%)$ dinyatakan IVA Test positif (Sukmawati, 2020). Kegiatan pengabdian ini bertujuan untuk meningkatkan pengetahuan masyarakat mengenai deteksi dini kanker payudara dan kanker serviks yang menjadi penyebab kematian dari banyak wanita baik di Indonesia maupun dunia.

\section{MASALAH}

Keterlambatan pasien kanker datang ke pelayanan kesehatan masih menjadi kendala penanganan kanker hingga saat ini. Kejadian keterlambatan penderita kanker payudara dalam pemeriksaan pertama kali ke pelayanan kesehatan di Indonesia mencapai lebih dari $80 \%$ 
sehingga ditemukan pada kondisi stadium lanjut. Begitu juga dengan kanker serviks, 70 persen penderita kanker serviks yang datang berobat ke rumah sakit sudah pada stadium lanjut, yaitu stadium II dan III sehingga sulit untuk disembuhkan (Dyanti, 2016).

Keterlambatan dalam pemeriksaan pertama kali ke pelayanan Kesehatan menujukkan bahwa kurangnya perilaku deteksi dini, serta kurangnya kesadaran dan pemahaman tentang kanker utamanya pada wanita yang memiliki faktor risiko terhadap kanker baik kanker payudara maupun kanker serviks (Isdamayanti, 2013). Rendahnya pengetahuan masyarakat tentang kanker, adanya keengganan masyarakat akan pemeriksaan secara dini, adanya rasa takut terhadap penyakit kanker serta penyakit kanker yang tidak menampakkan gejala pada stadium awal menyebabkan penderita kanker baru diketahui pada stadium lanjut sehingga sulit untuk disembuhkan yang mengakibatkan tingginya angka kematian dikarenakan kanker.

Penemuan dini kanker payudara dan serviks baik oleh individu maupun oleh petugas kesehatan adalah upaya yang dilakukan agar dapat ditempuh langkah-langkah yang lebih cepat dan tepat dalam penanganan kanker payudara dan serviks. Melalui deteksi dini diharapkan dapat meningkatkan kualitas hidup pasien serta mengurangi angka kematian yang diakibatkan oleh kanker payudara dan serviks.

Berdasarkan permasalahan-permasalahan yang telah disebutkan di atas, diperlukan adanya suatu sosialisasi kepada masyarakat mengenai kanker payudara dan serviks terutama cara untuk melakukan deteksi dini terhadap penyakit tersebut. Diharapkan dengan sosialisasi mengenai deteksi dini kanker payudara dan serviks, masyarakat bisa bertambah pengetahuannya sehingga dapat melakukan deteksi dini baik secara mandiri maupun melalui tenaga Kesehatan

\section{METODE}

Kegiatan sosialisasi deteksi dini kanker payudara dan serviks dilaksanakan secara online melalui webinar dengan judul "Yuk Kenal Lebih Jauh Dengan Kanker Pembunuh Wanita Di Dunia". Pemilihan metode online dikarenakan situasi pandemi Covid 19 yang masih melanda. Adapun aplikasi yang digunakan berupa aplikasi Zoom

Webinar dilaksanakan pada hari Sabtu tanggal 15 Agustus 2020 pukul 13.00 WIB. Webinar dihadiri oleh 50 orang peserta yang terdiri dari 2 orang pemateri, 1 orang moderator yang merupakan bidan desa dan 47 orang masyarakat yang berada di wilayah kerja Puskesmas Tarogong Garut terdiri dari para kader, tokoh masyarakat dan masyarakat umum. 
Webinar dimulai dengan pembukaan oleh moderator, pretest dengan mengajukan beberapa pertanyaan berkaitan dengan kanker payudara dan seviks, pemaparan materi tentang kanker serviks, pemaparan materi tentang kanker payudara, sesi tanya jawab/diskusi, dan diakhiri posttest dengan mengajukan pertanyaan yang sama dengan pertanyaan pada saat pretest. Kegiatan webinar berakhir pada pukul 15.30 WIB.

\section{HASIL DAN PEMBAHASAN}

\section{1) Hasil}

Pengabdian masyarakat ini dilatarbelakangi oleh tingginya angka kematian yang diakibatkan oleh kanker payudara dan kanker serviks baik di Indonesia maupun di dunia, yang mana kedua kanker tersebut disinyalir menjadi kanker pembunuh utama bagi para wanita. Sehingga di dalam pengambilan judul webinar pun lebih mengedepankan kalimat "Yuk Kenal Lebih Jauh Dengan Kanker Pembunuh Wanita Di Dunia".

Beberapa minggu sebelum hari pelaksanaan webinar, poster telah disebar secara online kepada masyarakat di wilayah kerja Puskesmas Tarogong Kabupaten Garut. Para peserta terlebih dahulu mendaftarkan diri kepada panitia webinar untuk melihat estimasi jumlah peserta kegiatan. Jumlah pendaftar yang tercatat sebanyak 52 orang, namun yang mengikuti kegiatan sebanyak 47 orang.

Kegiatan webinar dilaksanakan pada hari Sabtu tanggal 15 Agustus 2020 dimulai dari pukul 13.00 WIB. Adapun rincian kegiatan adalah sebagai berikut :
a. Pembukaan oleh moderator (Dina Mardiana, S.ST., S.KM., M.Kes).
b. Pretest (Panitia)
c. Materi 1 tentang kanker serviks (Desy Syswianti, S.ST., M.Kes).
d. Materi 2 tentang kanker payudara (Tri Wahyuni, S.ST., M.Keb).
e. Sesi tanya jawab/diskusi.
f. Posttest (Panitia)
g. Penutup dan kesimpulan oleh moderator.

Sebelum masuk kepada pemaparan materi 1 dan 2, panitia mengadakan pretest dengan cara menanyakan beberapa buah pertanyaan secara langsung kepada para peserta, namun sebagian besar pertanyaan tidak bisa terjawab. Selama pemaparan materi oleh pemateri 1 dan 2 para peserta terlihat antusias memperhatikan slide dalam power point yang ditampilkan. Begitu juga pada sesi tanya jawab/diskusi, banyak pertanyaan yang diajukan oleh para peserta 
melalui kolom Chat Zoom. Jumlah pertanyaan yang terkumpul dalam kolom Chat Zoom yaitu sebanyak 16 pertanyaan, diantaranya adalah :

Pertanyaan 1 dari Apriyanti :"Untuk vaksin HPV bisa didapat dimana, dan berapa biayanya?"

Pertanyaan 2 dari Popon Rohmah : "Untuk anak yang siklus menstruasinya tidak teratur apakah berbahaya?"

Pertanyaan 3 dari Lia: "Apakah berbahaya siklus haid yang maju dari jadwal biasanya?"

Pertanyaan 4 dari Isti : "Apa sajakah gejala dari kanker serviks?”

Pertanyaan 5 dari Lia : "Setelah melakukan papsmear atau IVA test bagaimana untuk tahu hasilnya normal atau tidak?"

Pertanyaan 6 dari Kokom : "Kapan waktu yang tepat untuk IVA test?”

Pertanyaan 7 dari Wulan: "Berapa tahun sekali harus IVA test?"

Pertanyaan 8 dari Rosandi : "Untuk seseorang yang pernah terkena kanker terus dia sembuh, apakah masih beresiko terkena kanker jenis lain?”

Pertanyaan 9 dari Iros : "Yang rentan terkena kanker apakah payudara kanan atau kiri?"

Pertanyaan 10 dari Tika Maryati : "Ketika seorang melakukan operasi pembesaran payudara apakah itu termasuk faktor penyebab terjadinya kanker?”

Pertanyaan 11 dari Rosandi : “Apakah kanker payudara bisa terjadi pada laki-laki?”

Pertanyaan 12 dari Rosandi : "Berapa persen resiko terjadi kanker payudara apabila menstruasi di bawah umur 12 tahun?”

Pertanyaan 13 dari Siska : "Kalau pingin tau hormon diri sendiri bagaimana caranya?"

Pertanyaan 14 dari Sumiyati : "Apakah benar jengkol bisa digunakan sebagai obat kanker?"

Pertanyaan 15 dari Nining : "Apakah menyusui dapat mencegah kanker payudara?"

Pertanyaan 16 dari Eti Setiawati : "Apakah benjolan yang ditemukan saat melakukan SADARI selalu kanker payudara?"

Di akhir sesi sebelum kegiatan berakhir, panitia mengadakan posttest sebagai bentuk evaluasi dengan cara mengajukan beberapa buah pertanyaan yang sama pada saat pretest. Dari semua pertanyaan yang diajukan, para peserta dapat menjawabnya dengan benar. Secara keseluruhan kegiatan webinar berjalan dengan lancar meskipun pada awal kegiatan terdapat sedikit kendala teknis berkaitan dengan jaringan/sinyal. Namun hal tersebut dapat segera teratasi dengan baik. Kegiatan webinar selesai pada pukul 15.30 WIB. 

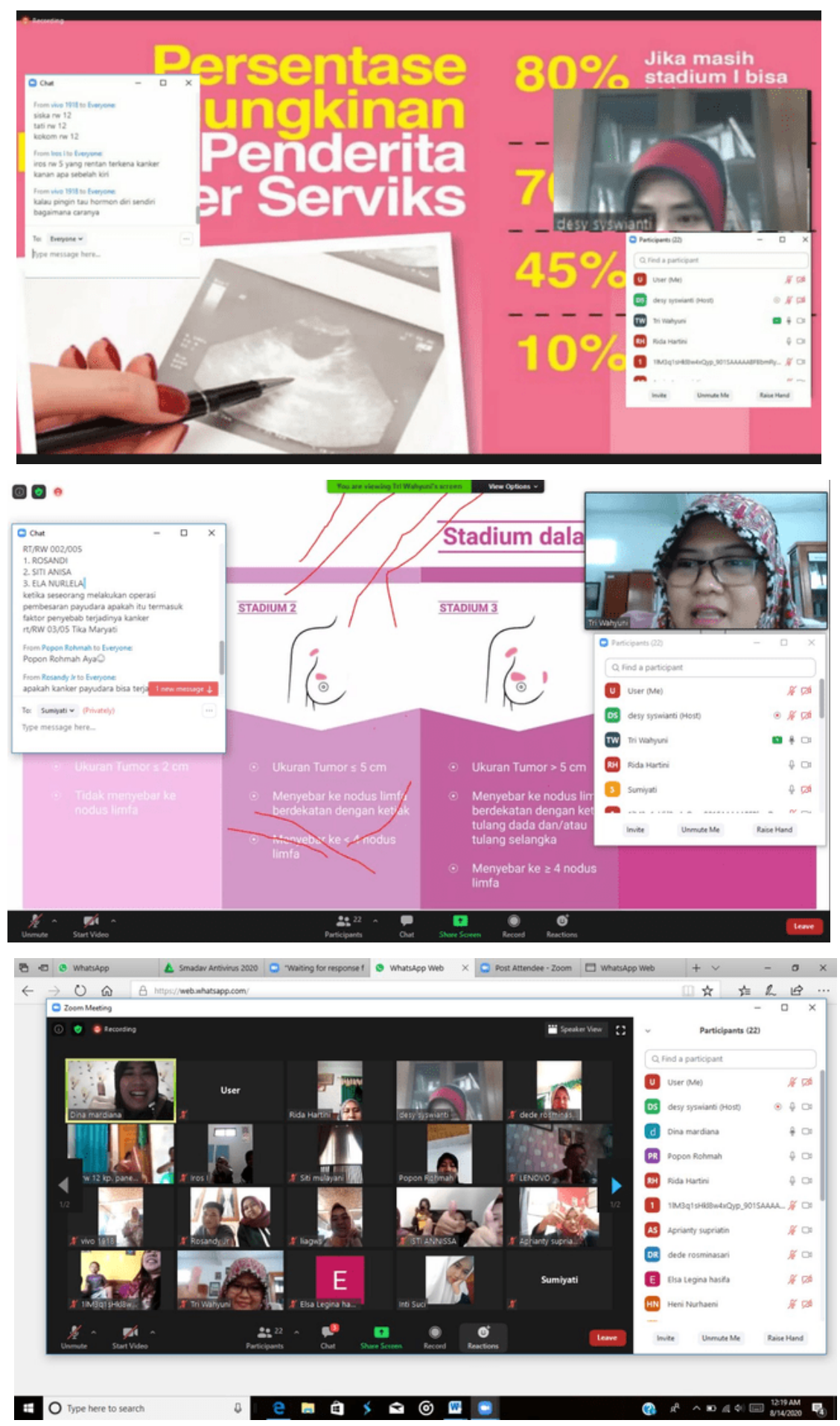

Gambar 1. Pelaksanaan Pengabdian

\section{2) Pembahasan}

Kanker merupakan salah satu penyebab kematian utama di seluruh dunia. Kanker adalah pertumbuhan yang tidak normal dari sel-sel jaringan tubuh yang berubah menjadi jaringan yang ganas dan dapat tumbuh lebih lanjut serta menyebar ke bagian tubuh lainnya 
sehingga dapat mengakibatkan kematian (Pusat Data dan Informasi Kementerian Kesehatan RI, 2016).

Penyakit kanker di Indonesia memiliki prevalensi yang cukup tinggi. Berdasarkan Riskesdas (2018) diketahui bahwa prevalensi kanker di Indonesia meningkat dari 1,4\% di tahun 2013 menjadi 1,8\% di tahun 2018. ${ }^{7}$ Terdapat dua jenis kanker yang paling banyak diderita wanita Indonesia, yaitu kanker payudara dan kanker serviks. Kanker payudara memiliki angka kejadian 42,1 per 100ribu penduduk dengan angka rata-rata kematian 17 per 100ribu penduduk. Sedangkan untuk kanker serviks yaitu sebesar 23,4 per 100ribu penduduk dengan angka kematian sebesar 13,9 per 100ribu penduduk (Badan Penelitian dan Pengembangan Kesehatan Kementerian Kesehatan Republik Indonesia, 2018). Berdasarkan data tersebut kanker payudara dan kanker serviks merupakan dua pembunuh utama wanita. Hal itulah yang melatarbelakangi penulis untuk melakukan pengabdian masyarakat ini.

Pengenalan penyakit kanker menjadi penting karena dapat menurunkan kasus baru. Sehingga diperlukannya upaya pencegahan deteksi dini untuk mempermudah mengenali faktor risiko dan gejala kanker. Deteksi Dini ini bertujuan untuk menemukan kasus kanker pada stadium dini sehingga dapat dilakukan pengobatan yang cepat dan tepat dan memberikan kesembuhan dan harapan hidup yang lebih lama (Pusat Data dan Informasi Kesehatan Kementerian Kesehatan RI, 2015). Sesuai dengan tujuan utama dari pengabdian masyarakat ini yaitu untuk meningkatkan pengetahuan masyarakat mengenai kanker payudara dan kanker serviks sehingga bisa melakukan deteksi secara dini terhadap penyakit kanker.

Pencegahan kanker payudara dilakukan melalui deteksi dini dengan cara pemeriksaan payudara sendiri (SADARI) yang bertujuan untuk menemukan kanker payudara stadium awal. Beberapa deteksi dini yang bisa digunakan untuk mengetahui keberadaan kanker serviks adalah Pap Smear, Pap net, servikografi, tes inspeksi visual asam asetat (IVA), tes high-risk type (HPV), kolposkopi, dan sitologi berbasis cairan. Dari beberapa macam metode dalam deteksi dini kanker serviks, tes IVA menjadi metode yang saat ini menjadi program pemerintah di seluruh puskesmas di Indonesia (Soebrachman A, 2011). Pada saat webinar dijelaskan tentang cara melakukan deteksi dini sesuai dengan teori-teori diatas dan lebih ditekankan kepada cara deteksi dini yang paling mudah dan murah yaitu pemeriksaan SADARI untuk deteksi kanker payudara dan pemeriksaan IVA untuk deteksi kanker serviks.

Kurangnya Tingkat Pengetahuan masyarakat mengenai kanker payudara dan serviks dan keengganan melakukan deteksi dini menyebabkan lebih dari $70 \%$ pasien mulai menjalani 
perawatan medis ketika sudah pada kondisi parah dan sulit disembuhkan (Qodri, 2017). Hal inilah yang mengakibatkan angka kematian akibat kanker payudara dan kanker serviks menjadi sangat tinggi. Dibutuhkan kesadaran diri untuk bisa secara rutin melakukan deteksi dini dengan cara meningkatan pengetahuan masyarakat akan pentingnya deteksi dini melalui kegiatan webinar yang telah dilakukan. Diharapkan dengan pemberian pengetahuan melalui kegiatan webinar ini, mayarakat akan menjadi lebih tahu sehingga terbiasa untuk melakukan deteksi dini.

Kemudahan akses informasi akan memungkinkan terwujudnya perubahan perilaku kesehatan khususnya pelaksanaan deteksi dini kanker payudara dan serviks (Yuliwati, 2012). Hal ini sesuai dengan pengabdian masyarakat ini dimana pada saat pemaparan materi tampak para peserta antusias dengan materi yang diberikan dan mengajukan pertanyaan berkaitan dengan materi yang disampaikan. Para peserta menyatakan siap dan bersedia untuk melakukan deteksi dini kanker payudara dan serviks baik secara mandiri maupun oleh petugas kesehatan. Diharapkan setelah pemberian sosialisasi melalui kegiatan webinar ini para masyarakat menjadi lebih paham mengenai kanker payudara dan kanker serviks dan dapat secara rutin melakukan deteksi dini.

\section{KESIMPULAN}

Tidak semua masyarakat memiliki pengetahuan yang baik mengenai kanker payudara dan serviks, sehingga tidak mengetahui cara untuk melakukan deteksi dini terhadap penyakit tersebut. Setelah diberikan sosialisasi melalui kegiatan webinar berjudul "Yuk Kenal Lebih Jauh Dengan Kanker Pembunuh Wanita Di Dunia", masyarakat menjadi lebih tahu dan paham tentang cara melakukan deteksi dini kanker payudara dan serviks, sehingga bersedia untuk melakukan deteksi dini

\section{DAFTAR PUSTAKA}

Badan Penelitian dan Pengembangan Kesehatan Kementerian Kesehatan Republik Indonesia. (2018). Hasil Utama Riskesdas.

Bray, F. et all. (2018). GLOBOCAN estimates of incidence and mortality worldwide for 36 cancers in 185 countries. American Cancer Society Journals, 68(6), i, 387-506.

Dyanti, G. A. (2016). Faktor-Faktor Keterlambatan Penderita Kanker Payudara Dalam Melakukan Pemeriksaan Awal Ke Pelayanan Kesehatan. Jurnal Kesehatan Masyarakat, Universitas Negeri Semarang. 
Isdamayanti, M. (2013). Gambaran Pola Penerimaan Penegakan Diagnostik dan Tindakan Terapi Kanker oleh Dokter pada Penderita Kanker Payudara di RSU Dokter Soedarso Pontianak. E-Jurnal Universitas Tanjungpura, 1(1).

Pusat Data dan Informasi Kementerian Kesehatan RI. (2016). Bulan Peduli Kanker Payudara. Oktober 20. https://pusdatin.kemkes.go.id/article/view/17013100001/bulan-pedulikanker-payudara.html

Pusat Data dan Informasi Kesehatan Kementerian Kesehatan RI. (2015). Situasi Penyakit Kanker. ISSN 2088-270X. https://www.kemkes.go.id/resources/download/pusdatin/buletin/buletin-kanker.pdf

Qodri, K. I. (2017). Pengaruh Penyuluhan Pengetahuan Tentang Deteksi Dini Kanker Serviks Pada Wali Murid TK Aba Tegallayang I Bantul. Universitas ‘Aisyiyah Yogyakarta.

Soebrachman A. (2011). Awas. 7 Kanker Paling Mematikan. Syura Media Utama.

Sukmawati. (2020). Pendidikan Kesehatan dan Pelaksanaan Iva Test pada Wanita Usia Subur. Jurnal Media Karya Kesehatan, 3(1).

Witdiawati. (2019). Pendidikan Kesehatan Deteksi Dini Kanker Payudara sebagai Upaya Promosi Kesehatan Wanita Pasangan Usia Subur. Jurnal Media Karya Kesehatan, 2(2).

Yuliwati. (2012). Faktor-faktor yang Berhubungan dengan Perilaku WUS dalam Deteksi Dini Kanker Leher Rahim Metode IVA di Wilayah Puskesmas Prembun, Kabupaten Kebumen Tahun 2012. Universitas Indonesia. 